\title{
Characteristics of Metamorphic Rock Magnetic Fabrics in the Nyalam Area of the Southern Tibet and Its Geological Significance, China
}

\author{
Zou Guangfu ${ }^{1}$, Zou Xin ${ }^{2,5}$, Mao Ying ${ }^{3}$, Mao Qiong ${ }^{4}$, Pan Zhongxi ${ }^{1}$, Zhuang Zhonghai ${ }^{1}$ and Zhu Tongxin ${ }^{1}$ \\ 1. Chengdu Institute of Geology and Mineral Resources, Chinese Geological Survey, Chengdu 610082, China \\ 2. Department of Psychology, Peking University, Beijing 100871, China \\ 3. Chengdu Comprehensive Rock and Mineral Testing Center, Chengdu 610081, China \\ 4. Institute of Exploration and Development, North China Oilfield, Renqiu 062552, China \\ 5. China Ocean Press, Beijing 100081, China
}

Received: March 10, 2015 / Accepted: March 25, 2015 / Published: April 25, 2015.

\begin{abstract}
This paper reports Precambrian rock magnetic fabrics in the Nyalam area of southern Tibet. The analytical results of magnetic fabrics show that the values of $\mathrm{H}$ are high ( $>10 \%$ in general), so the ductile deformations of the Precambrian rock are strong. The orientation of the maximum principal stress inferred from the minimum magnetic susceptibility is nearly S-N, NE-SW and NW-SE. The Flinn diagram of the magnetic fabrics show that the strain pattern is oblate and constrictional type. Magnetic foliation of great majority of rock samples is well developed and the magnetic lineation is poor and the magnetic susceptibility ellipsoid is flattened. The magnetic lineation of the minority rock samples is well developed and the magnetic foliation is poor and the magnetic susceptibility ellipsoid is prolate. According to the geological field and the magnetic fabrics, there are 3 times tectonic stress field in SN directed extruding, NW-SE directed extruding, NW-SE directed extension. It shows that the Nyalam area has undergone process the orientation of SN, NW-SE nappe structure and NW-SE directed extension structure. The change of tectonic stress is reflected by the field characteristics of the Precambrian rock magnetic fabrics that is the direct responding result of the arc-continental, continent-continental collision between the India and Asian continents in the late part of the Late Cretaceous to Late Eocene and subsequently shifted to intra-continental convergent, the plateau uplifting and extension structure stage since the Late Eocene.
\end{abstract}

Key words: Magnetic fabrics, structural deformation, metamorphic rock, the Nyalam area of southern Tibet.

\section{Introduction}

As the youngest orogenic belt formed by continent-continent collision in the world, Himalaya orogenic belt is a key area to study interaction of lithosphere-atmosphere-biosphere-hydrosphere and discuss uplifting mechanism of Qinghai-Tibet Plateau, evolution of Gondwana Land and formation and extinction of Paleo-Tethys Ocean as well as an ideal place for expounding changes in climate and ecological environment of Asia and even the whole world, and it is also a critical area to solve several

Corresponding author: Zou Guangfu, professor, main research fields: geology in Qinghai-Tibet plateau, petrology and regional geological survey. E-mail: zguangfu@163.com. major problems in geosciences currently. Therefore, the Himalaya orogenic belt is increasingly becoming a key and hot spot for research by international geoscientists. The Nyalam Precambrian metamorphic terrane is the most important metamorphic belt in the Himalayan, which is distributed in the area south of Mount Everest (Qomolangma) in Tibet (Fig. 1). It is an important part of the Himalayan orogenic belt. As well as it is a study the formation and evolution of Himalayan and Tibetan Plateau uplift history of an important window, so it has always been given much concern by the Chinese and foreign geologists [1-11].

Therefore, we study the paleomagnetic and magnetic fabric of the Precambrian metamorphic rocks which 


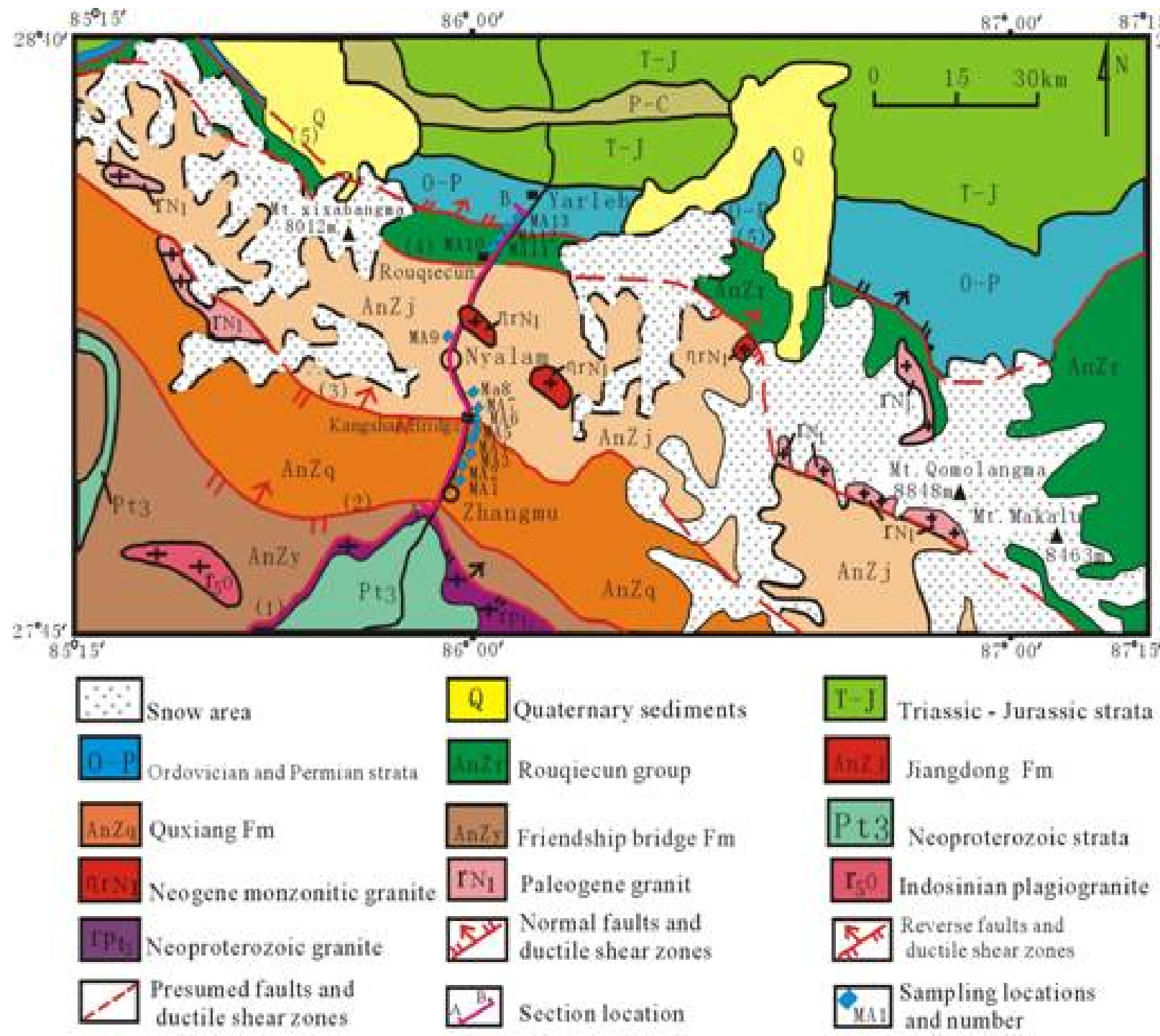

(1) Ok haldhunga fault;(2)Zhangmu fault and ductile shear zones (MCT);(3)Kangshanbridge fault and ductile shear zones; (4) Rouqiecun fault and ductile shear zones; (5) South Tibetan detachent system and ductile shear zones (STDS)

Fig. 1 Schematic geologic map of the study area and sampling location in the Nyalam area.

have important theoretical and practical significance in the area.

Since the twentieth century, many Chinese and foreign geologists have studied the Precambrian metamorphic rocks of Himalayan area and have made a lot of achievements [12-19]. Their work has promoted the study of the Himalayan orogen. So far, there are rarely publicly reported by other authors about paleomagnetism and magnetic fabric aspects in Himalayan region the Precambrian metamorphic terrane research trends and results.

The magnetic particles or magnetic minerals in rock have been the occurrence of recrystallization, ductile deformation, or alignment under stress and resulting in differences in susceptibility of different directions, which shows the anisotropy of magnetic susceptibility (AMS) of rocks. As deformed rocks, anisotropy of magnetic susceptibility (namely magnetic fabric) has well documented strain characteristics [20-21]. The use of magnetic fabric of rock deformation and tectonic deformation process is a new method of structural geology. Many scholars of international have studied and accumulated a certain amount of information in this area [22-26]. 
Many researchers have proved that the role of magnetic ellipsoid of rocks is equal to that of tectonic strain ellipsoid. They correspond to the three main axes and parallel to each other. The research is the use of magnetic fabric of tectonic deformation foundation. The parameters of magnetic fabric (such as P, T, F and L) can be used to describe the behaviors and periods of tectonic deformation [24-28]. Therefore, different rock magnetic fabric characteristics can be used to represent the role of different nature and different tectonic deformation of times. We can use the space directional of spindle and susceptibility ellipsoid shape to analyze structural deformation properties of rock deformation and stress experienced by the mode of action and direction.

Magnetic fabric method has a rapid and sensitive method and parameters that have become easy to test a new method to study tectonic deformation, which is widely used in terms of fault, ductile shear zone [29-31]. The studies have shown that can be used the characteristics of the minimum susceptibility axis to investigate the relative movement on both sides of the fracture block and the basis of the structural analysis [32, 33].

The Precambrian metamorphic belt in Nyalam region has located in southern Himalayan Plateau. It is the study of important areas about the formation and evolution of the Himalayan orogen and Tibetan Plateau uplift history. It's a complex tectonic deformation have to recorded the relevant information of crustal movement and deformation characteristics in southern Tibet Plateau in some extent. Its structure and anatomical deformation of acting have been to recognize the formation and evolution of the Himalayan good carrier. Therefore, the study area has been concerned by the geologists. However, existing studies are mainly from the regional geology, petrology, geochronology aspects fracture initiation activities and other aspects, relatively speaking, the lack of fine structural deformation and deformation of the times regional tectonic strain type and structure orientation of principal stress research. Due to lack of lithologic marker bed and depth of scientific research, the tectonic deformation and metamorphism process of understanding have inconsistent in the area. So far, there are some scientific problems need to be addressed in the Himalayan region: (1) Himalayan orogenic deformation and deformation characteristics of sub-problems; (2) the STDS (South Tibetan detachment system) and the MCT (main central thrust) nature and deformation characteristics of the problem; (3) the type and structure of regional tectonic strain principal stress orientation issues; (4) their collision between the Indian plate and Eurasian plate orogenic and tectonic uplift of the Tibetan Plateau intense process of relationship problems.

To solve these problems, we have studied the deformation of times and deformation and metamorphism of Precambrian metamorphic in Nyalam region, and the STDS and the MCT of deformation characteristics by measuring and calculating the parameters of the rock magnetic fabric of the Precambrian metamorphic in Nyalam region. We also have studied regional tectonic stress strain type and orientation of the main structure and so on in Nyalam region. Through the Precambrian metamorphic rock magnetic fabric conduct a more systematic analysis of testing research in the area. The magnetic fabric, tectonic strain characteristics, structural principal stress directions and kinematic characteristics of the Precambrian metamorphic basement area have been discussed in the paper. We provide a new evidence of the Precambrian metamorphic basement in Himalayan tectonic evolution. These studies investigate the formation of the Himalayan orogenic evolution and stress field conversion process has significant meaning.

\section{Geological Settings}

The study area is located in the crystalline basement complex zone between the STDS and the MCT demolition on the south of the Yarlung Zangbo River 
Plate Junction (Fig. 1). It is a set of the medium-deep Precambrian metamorphic rocks from the Nyalam rock group and Rouqiecun rock group composition. The Nyalam rock group can be further divided into the Friendship Bridge Formation, Quxiang Formation and Jiangdong Formation of three tectonolithostratigraphic Units. Tectonolithostratigraphic Units are separated by ductile shear faults [34]. They are NW-SE trending. Rouqiecun rock group located above Nyalam rock group. They are separated by Zaxizong ductile shear faults. It is NW-SE distribution. Between Rouqiecun rock group and Ordovician sedimentary cover of the Jiacun group $\left(\mathrm{O}_{1+2} \mathrm{j}\right)$ are separated by the South Tibetan detachment system ductile shear zones [34]. Rock group characterized as follows.

(1) Friendship Bridge Formation (AnZy) Located in Friendship Bridge to the south of Zhangmu in the most southern part of the study area, the cross-section is not bottomless (Fig. 1). Friendship Bridge rock group overall was gray, the lower gray kyanite mainly biotite schist, staurolite kyanite clip light gray biotite schist (garnet) biotite quartz schist, gray garnet biotite oblique long leptynite, biotite quartz schist. The upper part of the main light gray biotite quartz schist, garnet biotite quartz schist with gray biotite schist.

(2) Quxiang Formation (AnZq) located in the southern study area from Zhangmu to Kangshan Bridge (Fig. 1). The lower part is light gray with a gray garnet two-mica schist and sillimanite-quartz schist, biotite and plagioclase leptynite gneiss. The upper part is mainly light gray upper with a gray sillimanite-biotite monzonite leptynite and two-mica quartz schist and gneiss, biotite-quartz schist.

(3) Jiangdong Formation (AnZj) located in the middle of the study area (Fig. 1), the lower part is light gray banded biotite gneiss mixed, sillimanite augen granitic mylonite and diopside marble. The upper gray leptynite biotite-plagioclase, muscovite granitic mylonite, biotite gneiss.

(4) Rouqiecun group (AnZr) located in the northern part of the study area (Fig. 1), the lower part is light gray Seyan spherical granitic mylonite; greenish gray in the middle of thick-bedded marble and gray biotite leptynite; The upper part is gray biotite-plagioclase leptynite, light gray granitic mylonite, dark gray biotite leptynite mylonite clip light gray marble mylonite.

\section{Samples and Testing}

Samples of rock magnetic fabric are all collected in the measured profile, which ensures a representative sample, integrity, and reliability. Samples collected in the field using a Chinese production GSD-1 Portable portable sampling drill, drill core diameter of 24-25 $\mathrm{mm}$ (due to the differences in the degree of consolidation lithology changes slightly), length is generally 30-60 mm, with matching magnetic compass orientation directional coring, in accordance with sampling sites drill directional core the specimen (Fig. 1). Samples collected along the profile bottom-up, according to the spacing of 2-4 km arranged a mining point (Fig. 1). Quxiang Formation has eight sampling sites, sampling sites numbered MA1-MA8 and 120 specimens; Jiangdong Formation has a sampling sites (MA9) and 12 specimens; Rouqiecun group has two sampling sites, number of MA10, MA11 and 41 specimens; the main detachment faces of South Tibetan detachment system has two sampling sites, numbered MZ1, MZ2 and 102 specimens; A total of thirteen points and 241 samples were collected specimens. In the laboratory, the orientation of the core sample was cut into high 22-25 $\mathrm{mm}$ and diameter $25 \mathrm{~mm}$ cylindrical sample. Samples tested by the paleomagnetism Laboratory of Chengdu Institute of Geology and Mineral Resources, China. The test equipment for the HKB-1 type of Kappabridge magnetic susceptibility meter and accuracy of $2 \times 10^{-6} \mathrm{SI}$. Each sample was done fifteen different directions component testing, then calculate the parameters of the magnetic susceptibility and magnetic anisotropy. Sample test calculation results are shown in Table 1. 


\section{Magnetic Fabric and Its Tectonic Significance}

In recent years, the use of magnetic fabric of rocks to study the deformation of the rock is a means of structural geology. Because the distribution and arrangement of the magnetic substance determines the direction of the residual magnetization of the rock the maximum and minimum values. The directions of the maximum and minimum values related to the formation and deformation of the rock. Some Chinese and foreign scholars have carried out research in this area and have accumulated a certain amount of information [22, 32, 35, 36]. Chinese and foreign scholars study showed that the rock magnetic susceptibility ellipsoid is equivalent to the rock formations strain ellipsoid. The three axes of strain ellipsoid with three axes of magnetic susceptibility ellipsoid are parallel to each other and have some relationship of structure. Therefore, we can analyze to tectonic stress characteristics from the rock anisotropy of magnetic susceptibility and minimal susceptibility spindle orientation of magnetic susceptibility ellipsoid.

Magnetic fabric test results of the study area are listed in Table 1. From the test results in Table 1 and combined sample lithology, mineralogy, and tectonic deformation characteristics were analyzed. The area of rock magnetic fabric has the following characteristics.

\subsection{Rock Magnetic Susceptibility Value}

Rock magnetic susceptibility value difference in all kinds of rocks. It reflects the types of magnetic minerals and content in rock have little change. Overall, only the magnetic susceptibility of marbles is relatively high. Except the MA9 marble samples measured magnetic susceptibility (K1, K2, K3) value with other sample measured magnetic susceptibility has certain difference, Other different samples measured by magnetic susceptibility (K1, K2, K3) value were small. This shows that besides MA9 marble samples and the other magnetic minerals in the rock sample distribution more uniform. But MA9 marble samples and other samples of the magnetic foliation F, magnetic lineation, magnetic anisotropy thin $\mathrm{P}$ and the percentage of magnetic anisotropy $\mathrm{H}$ difference is small (Table 1). It also shows that the rock magnetic susceptibility ellipsoid shape and location parameters is relatively stable in this area.

\subsection{Strength of Rock Deformation}

Yan (1996) [37] believes that when the percentage of magnetic susceptibility anisotropy value is greater than $5 \%$, which shows that rock began to produce plastic deformation. The results show that the $\mathrm{H}$ value of the rocks in this area is greater than $10 \%$. The sample point MA1 micaschist of H (MA1) is 45.1\%, which is the highest value point in this area. The second is the sample point MA9 marble of $\mathrm{H}$ is $31.2 \%$ (Table 1). It shows that rock has experienced strong ductile plastic deformation. And field observations to the fact that these rocks have undergone ductile deformation is extremely consistent.

\subsection{Tectonic Principal Stress Orientation}

$\mathrm{K} 1, \mathrm{~K} 2$ and $\mathrm{K} 3$ are respectively corresponding to the maximum susceptibility spindle, intermediate susceptibility spindle and minimum susceptibility spindle, its unit is $1 \mathrm{O}^{-6} \mathrm{SI}$. The measured data is on the pole lower hemisphere equal-area projection (Fig. 2). The Fig. 2 shows that $\mathrm{K} 3$ is most concentrated, $\mathrm{K} 1$ is relatively concentrated and K2 relatively discrete. Between each spindle susceptibility ellipsoid and structural elements better correspondence. That magnetic lineations and tectonic lineation is correspondence. Magnetic foliation (K1 and K2 posed surface) and foliation, cleavage and bedding is consistent. The orientation of $\mathrm{K} 3$ is perpendicular to these foliation [30, 32, 36, 38-40].

In the study area, the Fig. 2 and Table 1 show that the $\mathrm{K} 3$ projection of the main points fall in the third quadrant and the fourth quadrant boundary or nearby in the six sampling sites (MA1 to MA6) of Quxiang 
Table 1 Table of the Precambrian rock magnetic fabrics parameters in the Nyalam area

\begin{tabular}{|c|c|c|c|c|c|c|c|c|c|c|c|c|c|c|c|}
\hline $\begin{array}{l}\text { Sample } \\
\text { point } \\
\text { number }\end{array}$ & $\begin{array}{l}\text { Sampling point } \\
\text { location }\end{array}$ & $\begin{array}{l}\text { t Number } \\
\text { of samples }\end{array}$ & Rock property & $\mathrm{K}_{1}$ & $\mathrm{~K}_{2}$ & $\mathrm{~K}_{3}$ & $\mathrm{~K}$ & $\mathrm{D}_{3}$ & $\mathrm{I}_{3}$ & $\mathrm{P}$ & $\mathrm{E}$ & $\mathrm{T}$ & $\mathrm{F}$ & $\mathrm{L}$ & $\mathrm{H}(\%)$ \\
\hline MA1 & $\begin{array}{l}\text { Zhangmu town } \\
\text { north }\end{array}$ & 26 & Two-mica schist & $2.73 \mathrm{E}+02$ & $2.57 \mathrm{E}+02$ & $1.68 \mathrm{E}+02$ & $2.33 \mathrm{E}+02$ & 190.1 & 60.6 & 1.72 & 1.49 & 0.76 & 1.60 & 1.07 & 45.07 \\
\hline MA2 & $\begin{array}{l}\text { From MA1 } \\
2 \mathrm{Km}\end{array}$ & 15 & Sillimanite gneiss & $4.05 E+02$ & $3.74 \mathrm{E}+02$ & $2.91 \mathrm{E}+02$ & $3.57 \mathrm{E}+02$ & 199.8 & 51.0 & 1.36 & 1.18 & 0.59 & 1.27 & 1.07 & 28.84 \\
\hline MA3 & $\begin{array}{l}\text { northern Ding } \\
\text { Renbu Bridge }\end{array}$ & 15 & Biotite monzonitic gneiss & $4.06 \mathrm{E}+02$ & $3.77 \mathrm{E}+02$ & $3.18 \mathrm{E}+02$ & $3.67 \mathrm{E}+02$ & 213.8 & 72.6 & 1.25 & 1.10 & 0.40 & 1.17 & 1.07 & 21.51 \\
\hline MA4 & Qu xiang east & 15 & $\begin{array}{l}\text { Banded biotite monzonitic } \\
\text { mixed gneiss }\end{array}$ & $1.37 \mathrm{E}+02$ & $1.34 \mathrm{E}+02$ & $1.20 \mathrm{E}+02$ & $1.30 \mathrm{E}+02$ & 203.6 & 58.6 & 1.15 & 1.09 & 0.62 & 1.12 & 1.03 & 13.68 \\
\hline MA5 & Qu xiang north & 16 & $\begin{array}{l}\text { Biotite-plagioclase gneiss } \\
\text { folder Biotite quartz schist }\end{array}$ & $1.92 \mathrm{E}+02$ & $1.84 \mathrm{E}+02$ & $1.68 \mathrm{E}+02$ & $1.81 \mathrm{E}+02$ & 164.5 & 45.7 & 1.14 & 1.04 & 0.27 & 1.09 & 1.05 & 12.96 \\
\hline MA6 & $\begin{array}{l}\text { Kangshanbridg } \\
\text { e south }\end{array}$ & 11 & Biotite plagioclase gneiss & $1.80 \mathrm{E}+02$ & $1.75 \mathrm{E}+02$ & $1.60 \mathrm{E}+02$ & $1.72 \mathrm{E}+02$ & 167.1 & 53.0 & 1.13 & 1.06 & 0.49 & 1.09 & 1.03 & 11.82 \\
\hline MA7 & $\begin{array}{l}\text { Kangshanbridg } \\
\text { e south }\end{array}$ & 13 & Augen granitic mylonite & $1.64 \mathrm{E}+02$ & $1.61 \mathrm{E}+02$ & $1.42 \mathrm{E}+02$ & $1.56 \mathrm{E}+02$ & 164.9 & 64.0 & 1.16 & 1.11 & 0.73 & 1.13 & 1.02 & 14.19 \\
\hline MA8 & $\begin{array}{l}\text { Kangshanbridg } \\
\text { e north }\end{array}$ & 13 & Biotite two feldspar gneiss & $1.61 \mathrm{E}+02$ & $1.56 \mathrm{E}+02$ & $1.40 \mathrm{E}+02$ & $1.53 \mathrm{E}+02$ & 177.9 & 52.2 & 1.15 & 1.07 & 0.44 & 1.11 & 1.04 & 13.51 \\
\hline MA9 & $\begin{array}{l}\text { Nyalam } \\
\text { County north }\end{array}$ & 14 & $\begin{array}{l}\text { Marble clip biotite plagioclase } \\
\text { leptynite }\end{array}$ & $1.41 \mathrm{E}+03$ & $1.28 \mathrm{E}+03$ & $8.23 E+02$ & $1.17 \mathrm{E}+03$ & 325.3 & 36.8 & 1.46 & 1.26 & 0.45 & 1.35 & 1.07 & 31.17 \\
\hline MA11 & Rouqiecun & 17 & Biotite plagioclase leptynite & $1.87 \mathrm{E}+02$ & $1.82 \mathrm{E}+02$ & $1.50 \mathrm{E}+02$ & $1.73 \mathrm{E}+02$ & 131.8 & 47.1 & 1.23 & 1.10 & 0.39 & 1.16 & 1.06 & 20.60 \\
\hline MZ1 & Jiacun & 18 & Muscovite granitic mylonite & $1.17 \mathrm{E}+01$ & $1.10 \mathrm{E}+01$ & $9.90 \mathrm{E}+00$ & $1.09 \mathrm{E}+01$ & 163.1 & 74.9 & 1.23 & 1.04 & 0.19 & 1.13 & 1.09 & 20.23 \\
\hline MZ2 & Jiacun & 44 & Mylonite & $1.06 \mathrm{E}+02$ & $9.71 \mathrm{E}+01$ & $8.61 \mathrm{E}+01$ & $9.62 \mathrm{E}+01$ & 147.5 & 58.8 & 1.20 & 1.04 & 0.27 & 1.12 & 1.07 & 17.66 \\
\hline
\end{tabular}

$\mathrm{K}_{1}$-the maximum principal susceptibility; $\mathrm{K}_{2}$ —middle of the main magnetic susceptibility; $\mathrm{K}_{3}$ —minimum principal susceptibility; $\mathrm{K}$-the average magnetic susceptibility; $\mathrm{D}_{3}$ and $\mathrm{I}_{3}$ —minimum principal susceptibility orientation and inclination; P—anisotropy of magnetic susceptibility; E—susceptibility ellipsoid flat rate; $\mathrm{T}$ - susceptibility ellipsoid shape factor; $\mathrm{F}$ - magnetic foliation; L-magnetic lineation; $\mathrm{H}$-percentage anisotropy. 

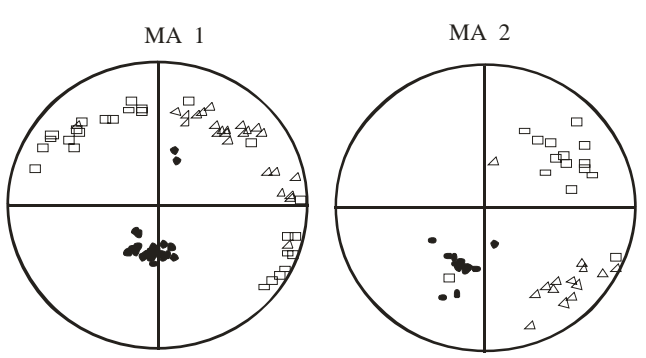

MA 6
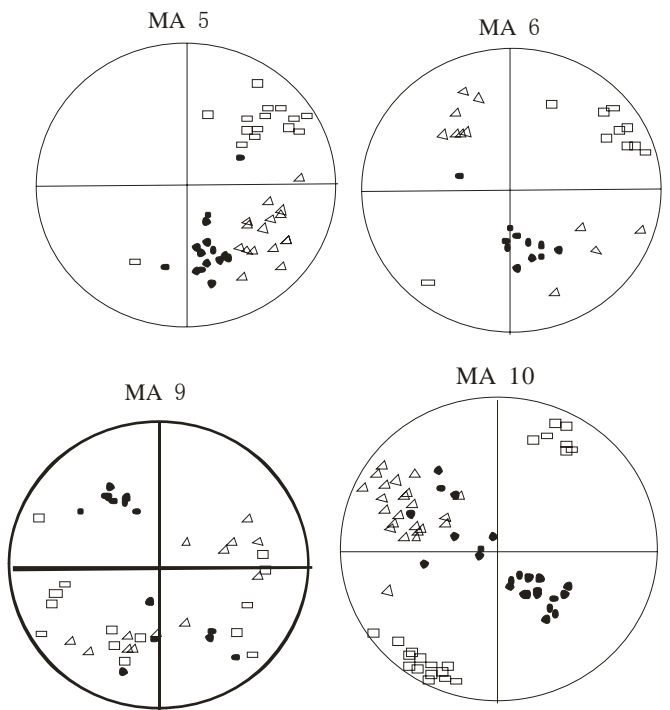

$\mathrm{K} 1 \triangle \mathrm{K} 2$
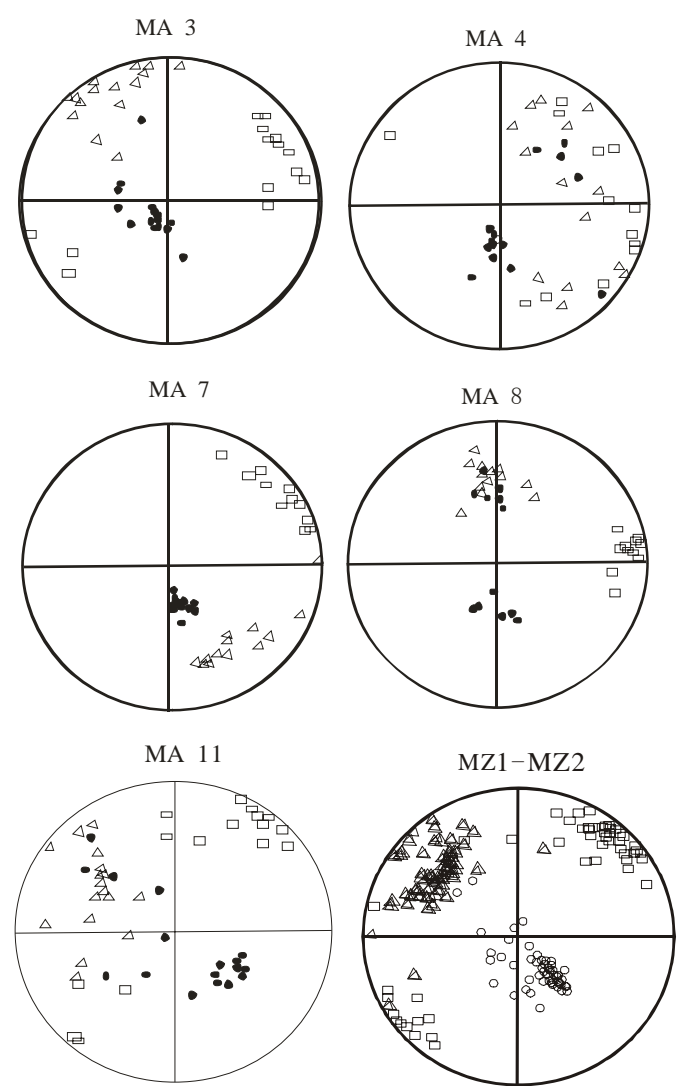

Fig. 2 Stereographic plots of anisotropy directions of the Precambrian rock magnetic fabrics in the Nyalam area.

Formation and two sampling sites (MA7 to MA8) Jiangdong Formation; the K3 projection point of MA3 sampling site that some fall in the second quadrant and the third quadrant; the K3 projection point of MA4 sampling site that some projection points fall in the fourth quadrant (Fig. 2). The minimum susceptibility spindle of sampling points MA1-MA8 rock magnetic fabric samples. Advantage values of declination and inclination of K3 respectively is, MA1 is $190.1^{\circ} \angle 60.6^{\circ}$, MA2 is $199.8^{\circ} \angle 51^{\circ}$, MA3 is $213.8^{\circ} \angle 72.6^{\circ}$, MA4 is $203.6^{\circ} \angle 58.6^{\circ}$, MA5 is $164.5^{\circ} \angle 45.7^{\circ}$, MA6 is $167.1^{\circ} \angle 53^{\circ}$, MA7 is $164.9^{\circ} \angle 64^{\circ}$ (Table 1 ). This shows that the section starting point Zhangmu to Kangshan Bridge area, the tectonic slices have major experienced by nearly SN direction principal stress and followed also by NE-SW direction stress.

In the north of Nyalam County, the K3 projection point of MA9 sample point in Jiangdong Formation major fall in the second quadrant, small fall in the third quadrant and the fourth quadrant (Fig. 2). Advantage values of declination and inclination of $\mathrm{K} 3$ is $325.3^{\circ} \angle 36.8^{\circ}$ (Table 1 ). The $\mathrm{K} 3$ projection point of the four sample points in the Rouqiecun group (MA10, MA11, MZ1, MZ2) falls mainly on the second quadrant and the fourth quadrant, a small amount falls between the third quadrant and fourth quadrant (Fig. 2). Advantage values of declination and inclination of $\mathrm{K} 3$ respectively is, MA10 is $137.4^{\circ} \angle 52.5^{\circ}$, MA11 is $131.8^{\circ} \angle 47.1^{\circ}$, MZ1 is $163.1^{\circ} \angle 74.9^{\circ}, \quad$ MZ2 is $147.5^{\circ} \angle \mathrm{L} 58.8^{\circ}$. This Indicates that MA9 mining point of the Jiangdong rock group to Rouqiecun Village group of Jiacun area in the North of Nyalam County, the tectonic slices have major subjected principal stress direction nearly northwest-southeast direction; experienced by nearly SN direction principal stress and followed also by NE-SW direction stress and followed also by nearly SN and NW-SE stress role (Fig. 2). 


\section{Characteristics of Metamorphic Rock Magnetic Fabrics in the Nyalam Area of the Southern Tibet and Its Geological Significance, China}

4.4 Flinn Diagram of Rock Magnetic Fabric and Strain Type

In the finite strain studies, people used Flinn diagrams to represent different types of uniform strain. In the magnetic fabric analysis, there are similar diagrams, with L (magnetic lineation) for the vertical axis to $\mathrm{F}$ (magnetic foliation) as the abscissa, the data projected on the coordinate system; with $\mathrm{E}=1$ for the sector, the coordinate system is divided into two regions, If $\mathrm{E}>1$, the ellipsoid is flat dome, rock foliation than well developed lineation; conversely, if $\mathrm{E}<1$, the ellipsoid is long dome, rock lineation than well developed foliation.

The rock magnetic fabric Flinn diagram (Fig. 3) in the study area shows that nine points of the Quxiang Formation and Jiangdong Formation (MA1 to MA9) sampled goods, the vast majority core of the magnetic parameters point fall in straight the following interval (Fig. 3). It indicates that the magnetic susceptibility ellipsoid is mainly oblate ellipsoid, which reflects the regional tectonic strain type is mainly compressive strain and with flattening mainly, the rock foliation developed better than the line. Only a few magnetic parameters point falls $\mathrm{E}<1$ interval (Fig. 3), Magnetic susceptibility ellipsoid values expressed as elongated shape, the area has also been reflected in the regional extension tectonics, it is entirely consistent with our observation in the field. In the four sampling points (MA10, MA11, MZ1, MZ2) of the Rouqiecun group and the South Tibetan detachment system sampled product, Magnetic parameters point of MA10 and MA11 core sampling points accounted for $24 \%$ of the total sample, which fall in Flinn diagram of the upper left $(E<1)$, Magnetic susceptibility values ellipsoid expressed as elongated shape; accounted for $76 \%$ of the total sample point falls in lower right $(\mathrm{E}>1)$, Magnetic susceptibility values ellipsoid showed flattened shape (Fig. 3). The core magnetic parameters point of MZ1 and MZ2 sampling points fall in Flinn diagram of the upper left $(<1)$ and accounting for $21 \%$ of the projected point total sample point. The magnetic susceptibility values expressed as elongated ellipsoid shape and accounted for $79 \%$ of the total sample point falls lower right $(\mathrm{E}>1)$. Their agnetic susceptibility values show flattened ellipsoid shape. It reflects that the regional tectonic strain type is mainly compressive strain to flattening based. Rock foliation joint development than the line. Meanwhile, some of the magnetic susceptibility magnitude ellipsoid parameters point performance of elongated shape, which describes that the area was also affected by regional tectonic extension. This is consistent with the field of geological phenomena observed by author. According to minimum susceptibility axis reflects that the main stress orientation of the South Tibetan detachment system is nearly the NW-SE, NE-SW and the nearly $\mathrm{S}-\mathrm{N}$ direction. This indicates that the main detachment surface stress of the South Tibetan detachment system once has three possible tectonic settings: Early stage, the South Tibetan detachment system subjected to compressive stress nearly SN, while generating the overthrust tectonics from north to south. The second phase, it subjected to compressive stress by the NW-SE direction, while generating the overthrust tectonic from the NW to SE and dextral strike-slip shear tectonics. The third phase, it subjected to being NW-SW trending extensional tectonics and NE-SW compressive stress.

\subsection{South Tibetan Detachment System Ductile Shear Zone Movement}

The south Tibetan detachment system (STDS) performances of a ductile shear zones, which strike nearly $290^{\circ}$, inclination $20^{\circ}-40^{\circ}$. If the $290^{\circ}$ as the approximate position of the ductile shear zone, according to the previous core magnetic parameters point of MA10 and MA11 projection point of sampling points, about $76 \%$ to $79 \%$ of the points will fall in Flinn diagram bottom right $(\mathrm{E}>1)$ (Fig. 3). Magnetic susceptibility values showed flattened ellipsoid shape and the smallest magnetic susceptibility spindle of angle and inclination the advantage values 

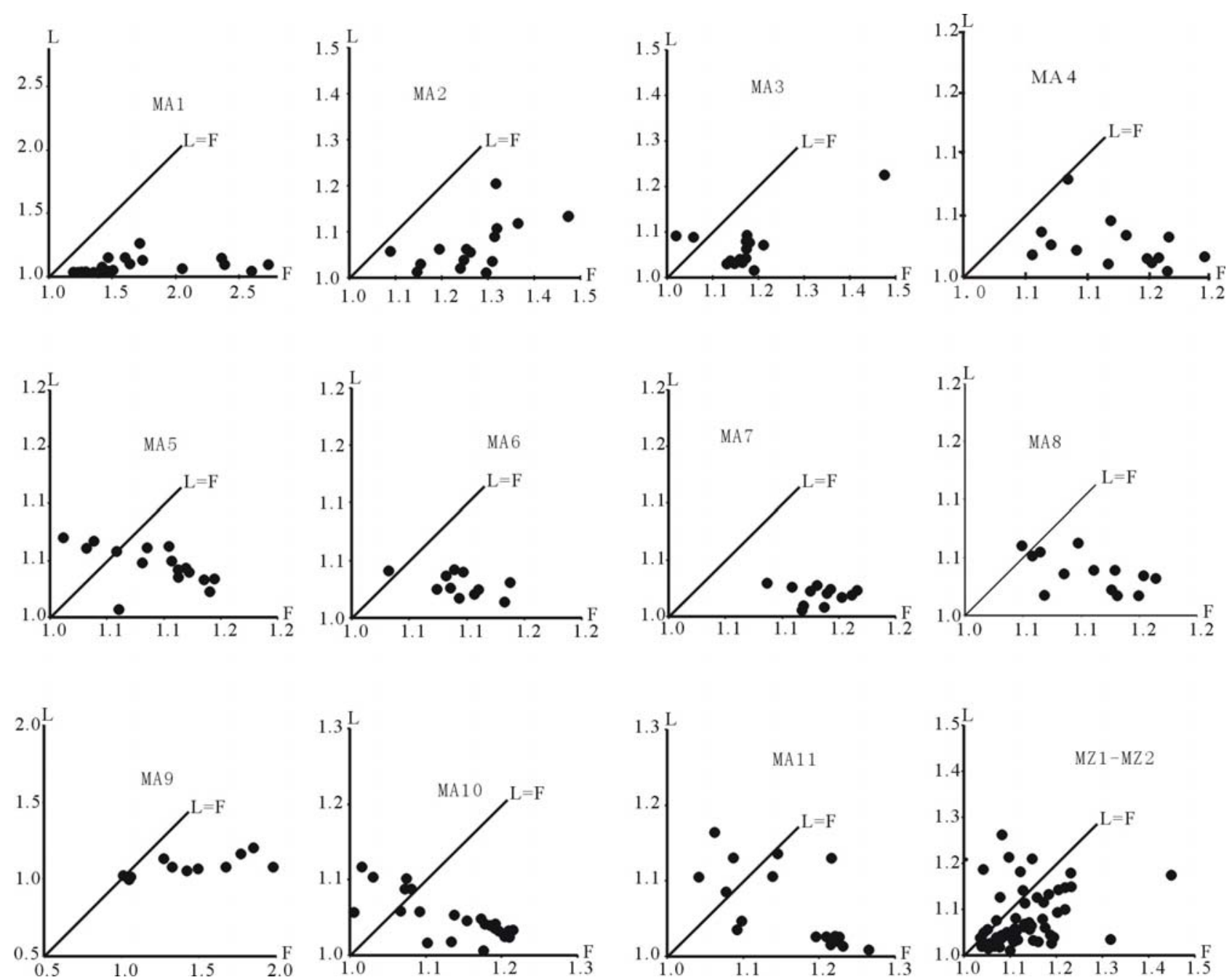

Fig. 3 Flinn diagram of the Precambrian rock magnetic fabrics in the Nyalam area.

were $\mathrm{MZ1}$ is $163.1^{\circ} \angle 74.9^{\circ}, \mathrm{MZ2}$ is $147.5^{\circ} \angle 58.8^{\circ}$ (Fig. 3). This indicates that the main direction of the rock stress is NW-SE direction, which reflects the regional tectonic strain type is mainly NW-SE compression strain. Using the minimum principal susceptibility orientation point analysis, through the minimum principal stress of magnetic susceptibility axis can determine that the horizontal movement of the ductile shear zone was dextral movement for a pressure of dextral strike-slip ductile shear zone. About the vertical movement of the nature of shear zone, in MA10 and MA11 the core sampling points, 62 samples were tested, 58 samples of the smallest magnetic susceptibility tends is SE or SSW direction. The SSW plate shows rise and the NEE plate down. In addition, four samples susceptibility minimum tends is NW, which shows that the NNE plate rises and the SSW plate down. It shows the process of ductile deformation, ductile shear zones both sides have declined to rise and dynamic characteristic sprimarily upward movement. Therefore, the movement of the ductile shear zone has three stages. At early times, it is nearly SN direction compressive stress and produce from north to south of the overthrust tectonics; the second stage, it subjects to NW-SE direction compressive stress, while generating the north west to south east of the overthrust tectonic and dextral strike-slip shear tectonics; the third phase, it subjects to NW-SW trending extensional tectonics and NE-SW direction compressive stress. 


\section{Characteristics of Metamorphic Rock Magnetic Fabrics in the Nyalam Area of the Southern Tibet and Its Geological Significance, China}

In summary, the change of tectonic stress is reflected by the field characteristics of the Precambrian rock magnetic fabrics that is the direct responding result of the arc-continental, continent-continental collision between the India and Asian continents in the late part of the Late Cretaceous to Late Eocene and subsequently shifted to intra-continental convergent, the plateau uplifting and extension structure stage since the Late Eocene.

\section{Conclusions}

(1) The analytical results of magnetic fabrics show that the values of $\mathrm{H}$ are high ( $>10 \%$ in general), so the ductile deformations of the Precambrian rock is strong. These characteristics and field observations to ductile deformation of these rocks are very consistent.

(2) The orientation of the maximum principal stress inferred from the minimum magnetic susceptibility is nearly S-N, NE-SW and NW-SE.

(3) The Flinn diagram of the magnetic fabrics show that the strain pattern is oblate and constrictional type. Magnetic foliation of great majority of rock samples is well developed and the magnetic lineation is poor and the magnetic susceptibility ellipsoid is flattened. The magnetic lineation of the minority rock samples is well developed and the magnetic foliation is poor and the magnetic susceptibility ellipsoid is prolate.

(4) The geological field and the magnetic fabrics show that there are 3 times tectonic stress field in $\mathrm{SN}$ directed extruding, NW-SE directed extruding, NW-SE directed extension. It shows that the Nyalam area has undergone process the orientation of $\mathrm{SN}$, NW-SE nappe structure and NW-SE directed extension structure. The change of tectonic stress is reflected by the field characteristics of the Precambrian rock magnetic fabrics that is the direct responding result of the arc-continental, continent-continental collision between the India and Asian continents in the late part of the Late Cretaceous to Late Eocene and subsequently shifted to intra-continental convergent, the plateau uplifting and extension structure stage since the Late Eocene.

\section{Acknowledgements}

This work was supported by China Geological Survey (Grant No. H45C004002, 1212010784007) and the Project of the National Natural Science Foundation of China (Grant No. 40272012).

\section{References}

[1] QTPCSITCAS (Qinghai-Tibet Plateau Comprehensive Scientific Investigation Team of Chinese Academy of Sciences). 1979. A Report of Scientific Expedition in the Mt. Jolmolangma Region (Geology). Beijing: Science Press.

[2] Liu, Z. Q., Yu, X. J., Xu, X., Pan, G. T. 1980. “The Basic Geological Characteristics of the Qinghai-Xizang (Tibet) Plateau.” Acta Geoscientia Sinica 2: 23-46.

[3] Achache, J., Courtillot, V., and Zhou, Y. X. 1984. "Paleogeographic and Tectonic Evolution of South Tibet since Middle Cretaceous Time: New Paleomagnetic Data and Synthesis.” J. Geophys Res. 89: 10311-39.

[4] Burchfiel, B. C., and Royden, I. H. 1985. "North-S outh Extension within the Convergent Himalayan Region." Geology 13: 679-82.

[5] Burchfiel, B. C., Chen, Z. L., Hodges, K. V., Liu, Y. P., Royden, L. H., Deng, C., and Xu, J. 1992. "The South Tibetan Detachment System, Himalayan Orogen: Extension Contemporaneous with and Parallel to Shortening in a Collisional Mountain Belt.” GSA Special Paper 269: 1-41.

[6] Chen, Z. L., and Liu, Y. P. 1996. "The South Tibetan Detachment System.” Tethyan Geology 20: 31-51.

[7] Pan, G. T. "An Evolution of Tethys in Global Ocean-Continent Transformation.” Tethyan Geology 18: 23-39.

[8] Molnar, P. 1984. "Structure and Tectonics of the Himalayas: Constraints and Implications of Geophysical Data." Annual Review of Earth and Planetary Sciences 12: 489-518.

[9] Mo, X. X., Zhao, Z. D., Zhou, S., Dong, G. C., and Liao, Z. L. 2007. "On the Timing of India-Asia Continental Collision.” Geological Bulletin of China 26: 1240-4.

[10] Zou, G. F., Zhou, M. K., Zhu, T. X., Wang, J., Feng, X. T. 2007. "Sedimentary Evolution of the Phanerozoic of North Slope Area of Mount Qomolangma, Tibet.” Journal of Palaeogeography 9: 1-12.

[11] Mao, Q., Zou, G. F., Gu, X. M., and Chen, L. 2012. "Geochemical Features and Tectonic Setting of Granites in Gangba-Dingri Area of Southern Tibet." Journal of Mineralogy and Petrology 32: 67-73. 
[12] Mu, E. Z., Wen, S. X., Wang, Y. G., Zhang, B. G., and Yin, J. X. 1973. "Stratigraphy of the Mount Jolmo Lungma Region in Southern Tibet, China.” Science in China, Ser. A 21: 59-71.

[13] BGMRX (Bureau of Geology and Mineral Resources of Xizang Autonomous Region), 1997. Stratigraphy (lithostratic) of Xizang Autonomous Region. Wuhan: China University of Geosciences Press.

[14] BGMRX (Bureau of Geology and Mineral Resources of Xizang Autonomous Region), 1993. Regional Geology of Xizang (Tibet) Autonomous Region. Beijing: Geological Publishing House.

[15] Zhang, Q., and Li, S. H. 1981. Tibet Magmatism and Metamorphism. Beijing: Science Press.

[16] Xu, R. H., Chen, Z. L., Gui, X. T., and Wang, J. W. 1986. "A Study of the Main Metamorphic Age of Nyalam Group (Tibet ).” Acta Petrologica Sinica 2: 13-22.

[17] Wei, G. Y., Shi, S. Q., Mao, Y. S., and Sun, S. H. 1989. Precambrian Geological Structure and Metamorphism in Himalayan Region. Chengdu: Chengdu University of Science and Technology Press.

[18] An, Z. S. 2001. "Evolution of Asian Monsoons and Phased Uplift of the Himalaya-Tibet an Plateau since Late Miocene Times.” Nature 411: 62-6.

[19] Zou, G. F., Pan, Z. X., Zhuang, Z. H., Zhu, T. X., Li, J. Z., and Feng, X. T. 2013. "Phanerozoic Paleomagnetism Characteristics of the Qomolangma Area in Tibet.” Acta Geologica Sinica 87: 517-27.

[20] Hou, G. T., Wang, C. C., and Li, L. 2010. "Magnetic Fabric Evidences for the Late Paleoproterozoic Mafic Dyke Swarm Emplacement, Southern Margin of the North China Craton.” Acta Petrologica Sinica 26: 318-24.

[21] Zhou, Y., Zhou, P., Wu, S. M., Shi, X. B., and Zhang, J. J. 2002. "Magnetic Fabric Study across the Ailao Shan-Red River Shear Zone.” Tectonophysics 346: 137-50.

[22] Kliefield, W., Owens, W., and Lowric, W. 1981. "Magnetic Susceptibility Anisotropy, Strain and Progres sive Deformation in Permian Sediment from Maritime Alps (France).” Earth and Planetary Science Letters 55: $181-9$.

[23] Huouda, F. 1982. "Magnetic Anis Otropy of Rocks and Its Application in Geology and Geophysics.” Geophysical Surveys 5: 37-82.

[24] Rathore, J. S. 1983. "Magnetic Fabric in Rocks from the Moll-Dran Valley.” Geologische Rundschau 72: 1081-104.

[25] Rathore, J. S., and Kafafy, A. M. 1986. “A Magnetic Fabric Study of the Shape Region in the English Lake District.” Journal of Structural Geology 8: 69-77.

[26] Yu, Q. F., and Zheng, M. 1992. The Rock Magnetic
Fabric Analysis and Geological Applications. Beijing: Geological Publishing House.

[27] Borradaile, G., Alford, C. 1987. "Relationship between Magnetic Susceptibility and Strain in Laboratory Experiments.” Tectonophysics 133: 121-35.

[28] Borradaile, G., and Alford, C. 1988. "Experimental Shear Zones and Magnetic Fabrics.” Journal of Structural Geology 10: 895-904.

[29] Rathore, J. S. 1985. "Some Magnetic Fabric Characteristics of Sheared Zones." Journal of Geodynamics 2: 291-301.

[30] Zhou, Y., Xu, R. H., Yan, Y. H., Yang, T. F., Luo, W., and Pan, Y. S. 2000. "Characteristics of Magnetic Fabrics of the Karakoram Fault Belt and Its Tectonic Significance.” Acta Petrologica Sinica 16: 134-44.

[31] Levi, T., and Weinberger, R. 2011. "Magnetic Fabrics of Diamagnetic Rocks and the Strain Field Associated with the Dead Sea Fault, Northern Israel." Journal of Structural Geology 33: 566-78.

[32] Rathore, J. S., Becke, M. 1980. “Magnetic Analyses in the Gail Valley (Garinthia, Austria) for the Determination of the Sense of Movements along This Region of the Periadriatic Line.” Tectonophysics 69: 349-68.

[33] Lu, R. K., Zhang, G. W., Zhong, H. M., Xia, J., Tong, J. S., and Yu, X. J. 2008. "Characteristics of Magnetic Fabrics in Western Segment of the Altun Fault Belt and Its Tectonic Significance." Chinese Journal of Geophysics 51: 752-61.

[34] Zou, G. F., Zhu, T. X., Jia, B. J., and Zhou, M. K. 2006. "Precambrian Crystalline Basement in the Nyalam Region, Southern Xizang.” Sedimentary Geology and Tethyan Geology 26: 13-9.

[35] Xu, B. A. 1990. "Magnetic Susceptibility Anisotrppy of Rocks and Its Application in Geology.” Geology and Prospecting 26: 39-46.

[36] Huang, B. C., Wang, Y. C., Zhu, R. X. 2003. "New Results of Magnetic Fabrics and Paleomagnetism of the Early Cretaceous Rocks in Turpan Intermountain Basins.” Science in China (Series D) 33: 363-72.

[37] Yan, G. L. 1996. The Application of Anisotropy of Magnetic Susceptibility to Geosciences. Wuhan: China University of Geosciences Press.

[38] Borradaile, G. J., and Tartning, D. H. 1981. "The Influence of Deformation on Magnetic Fabric in Weakly Deformed Rocks.” Tectonophysics 77: 151-68.

[39] Borradaile, G., and Alford, C. 1988. "Experimental Shear Zones and Magnetic Fabrics.” Journal of Structural Geology 10: 895-904.

[40] Borradaile, G. J., and Henry, B. 1997. "Tectonic Application of Magnetic Susceptibility and Its Anisotropy.” Earth-Science Review 42: 49-3. 